\title{
Seagrasses in the age of sea turtle conservation and shark overfishing
}

\author{
Michael R. Heithaus ${ }^{1}$, Teresa Alcoverro ${ }^{2,3}$, Rohan Arthur ${ }^{3}$, Derek A. Burkholder ${ }^{1}$, Kathryn A. Coates ${ }^{4}$, \\ Marjolijn J. A. Christianen ${ }^{5}$, Nachiket Kelkar ${ }^{3}$, Sarah A. Manuel ${ }^{4}$, Aaron J. Wirsing ${ }^{6}$, \\ W. Judson Kenworthy ${ }^{7}$ and James W. Fourqurean ${ }^{1,8 *}$
}

${ }^{1}$ Marine Science Program, Department of Biological Sciences, School of the Environment, Arts and Society, Florida International University, North Miami, FL, USA

${ }^{2}$ Centre d'Estudis Avançats de Blanes (CSIC), Blanes, Spain

${ }^{3}$ Oceans and Coasts Program, Nature Conservation Foundation, Karnataka, India

${ }^{4}$ Department of Conservation Services, Government of Bermuda, Flatts, Bermuda

${ }^{5}$ Department of Environmental Science, Faculty of Science, Institute for Water and Wetland Research, Radboud University Nijmegen, Nijmegen, Netherlands

${ }^{6}$ School of Environmental and Forest Sciences, University of Washington, Seattle, WA, USA

7 Center for Coastal Fisheries and Habitat Research, National Ocean Service, National Oceanic and Atmospheric Administration, Beaufort, NC, USA (Retired)

${ }^{8}$ Southeast Environmental Research Center, Florida International University, Miami, FL, USA

\section{Edited by:}

Stelios Katsanevakis, Institute for Environment and Sustainability, Italy

Reviewed by:

Lorien C. Pichegru, University of

Cape Town, South Africa

Maria Cristina Gambi, Stazione

Zoologica Anton Dohrn, Italy

Gary Andrew Kendrick, The

University of Western Australia,

Australia

\section{*Correspondence:}

James W. Fourqurean, Department of Biological Sciences and

Southeast Environmental Research Center, Florida International

University, 11200 SW, 8th St., OE

148, Miami, FL 33199, USA

e-mail: jim.fourqurean@fiu.edu
Efforts to conserve globally declining herbivorous green sea turtles have resulted in promising growth of some populations. These trends could significantly impact critical ecosystem services provided by seagrass meadows on which turtles feed. Expanding turtle populations could improve seagrass ecosystem health by removing seagrass biomass and preventing of the formation of sediment anoxia. However, overfishing of large sharks, the primary green turtle predators, could facilitate turtle populations growing beyond historical sizes and trigger detrimental ecosystem impacts mirroring those on land when top predators were extirpated. Experimental data from multiple ocean basins suggest that increasing turtle populations can negatively impact seagrasses, including triggering virtual ecosystem collapse. Impacts of large turtle populations on seagrasses are reduced in the presence of intact shark populations. Healthy populations of sharks and turtles, therefore, are likely vital to restoring or maintaining seagrass ecosystem structure, function, and their value in supporting fisheries and as a carbon sink.

Keywords: overgrazing, top-down control, conservation, marine protected areas, sharks, sea turtles

\section{INTRODUCTION}

Large-scale changes in ecosystems-from eutrophication and climate change to the loss of large-bodied herbivores and top predators (trophic downgrading) - have made understanding the importance of top-down forces in shaping ecosystem structure and function critical for effective management of ecosystems (Estes et al., 2011; Zarnetske et al., 2012). While studies from diverse ecosystems show that trophic downgrading is associated with large-scale changes in ecosystem structure (Estes et al., 2011), the importance of top-down forcing in seagrass ecosystems remains debated (Heck and Valentine, 2007). Seagrasses are critically important ecosystems that are declining at very high and accelerating rates (Waycott et al., 2009). Although most seagrass losses have been driven by poor coastal zone management that leads to increases in nutrient availability and decreases in water clarity (Short and Wyllie-Echeverria, 1996), the potential for disruption of top-down processes to drive some of these declines has been largely overlooked. While it is certain that in some seagrass ecosystems direct herbivory remains an important energy flow pathway (Heck and Valentine, 2007), there was so little evidence of direct grazing on seagrass leaves in the middle part of the 20th century that the prevailing paradigm was that such grazing was of minor importance to the energy flow in seagrass ecosystems. More recently, however, there has been a paradigm shift to the view that large-bodied grazers, particularly green sea turtles (Chelonia mydas), were critical in maintaining relatively heavily grazed, but healthy, seagrass ecosystems (Jackson et al., 2001; Bjorndal and Jackson, 2003). In fact, the argument has been made that sea turtles and seagrasses have coevolved a reciprocal dependence and that natural densities of green turtles could help reduce the detrimental impacts of eutrophication on seagrass beds through increased rates of nutrient uptake under heavy grazing (Jackson et al., 2001; Christianen et al., 2012).

Mirroring megafaunal declines on land (Estes et al., 2011), however, humans have greatly depleted populations of green turtles virtually worldwide, which likely has altered seagrass ecosystems (Jackson et al., 2001). For example, the seagrass dieoff in Florida Bay in the 1980s - generally thought to be a result of sulfide toxicity driven by high seagrass biomass and hypoxia (Borum et al., 2005; Koch et al., 2007)—has been hypothesized to have been caused by the loss of green turtles which would have prevented the accumulation of large biomass and the subsequent hypoxia (Jackson et al., 2001). This emerging 
view of the central role of grazing, particularly by turtles, has led to the idea that the restoration of turtle populations to historical levels is important for maintaining healthy seagrass ecosystems.

Although in many parts of the world green turtles remain highly threatened, recent conservation efforts to protect nesting beaches and reduce fishing pressure have been highly successful in some areas. Green turtle populations using major nesting beaches around the world have been increasing at $4-14 \%$ per year over the past two to three decades (Chaloupka et al., 2008). Whether extant seagrass systems can functionally sustain these increases in turtle numbers remains unknown in part because little is known about the factors controlling population densities of large juvenile and adult turtles under natural conditions. Because predators of turtles-large sharks (Heithaus, 2013) have declined precipitously around the world (Ferretti et al., 2010), understanding whether increasing turtle populations will lead to healthy seagrass ecosystems is a critical conservation and management concern. Indeed, lessons from terrestrial ecosystems suggest that herbivore populations released from predation and predation risk can alter the structure and function of primary producer communities (Estes et al., 2011), and recent observations in marine protected areas in Indonesia suggest increasing sea turtle grazing within protected areas is leading to degradation of the seagrass meadows that the turtles graze upon (Christianen et al., 2014). Given the very high value placed on the ecosystem services contributed by seagrass meadows (Barbier et al., 2011), including water quality protection, erosion control, biodiversity enhancement, fisheries production and climate change mitigation (Fourqurean et al., 2012), and the rapid and accelerating decline of these ecosystems (Waycott et al., 2009), it is paramount that we understand all of the factors contributing to healthy seagrass communities, including top-down control.

\section{MATERIALS AND METHODS}

The impacts of green turtles on seagrass communities were investigated in Bermuda (Northwest Atlantic Ocean), Shark Bay (Western Australia, Eastern Indian Ocean), Derawan (Indonesia), and Lakshadweep (India, Central Indian Ocean). Green sea turtle abundance is qualitatively high at all of these sites, although data on population density of turtles are lacking. Individual studies employed a variety of methods. In Shark Bay, turtles and dugongs were excluded from foraging within $202.5 \times 3 \mathrm{~m}$ plots (10 in safe and 10 in dangerous habitats, as defined by risk of tiger shark predation) using rebar cages with a $20 \mathrm{~cm}$ square mesh (Burkholder et al., 2013). Exclosures were maintained for 600 days in habitats that varied in the risk turtles face from tiger sharks (Heithaus et al., 2006, 2007). Twenty paired control plots consisted of a reference stake within $20 \mathrm{~m}$ of exclosures. The most abundant seagrass species in this study included Amphibolis antarctica, Halodule uninervis, Cymodocea angustata, and Halophila ovalis. Similar exclosures were used in Bermuda, where rates of primary production of Thalassia testudinum, measured as leaf growth rate (Zieman, 1974), were measured after 1 year in 3 exclosures and three control plots (Fourqurean et al., 2010). Similarly, in Derawan, turtle exclosure cages were monitored for 90 days and compared to plots in existing seagrass (H. uninervis) beds that were exposed to grazing (Christianen et al., 2012).

In Lakshadweep, India (Lal et al., 2010) the effects of long-term turtle grazing were quantified by measuring seagrass (Cymodocea rotundata and Thalassia hemprichii) canopy height, petiole length and leaf width inside natural exclosures (ungrazed plots) and outside (grazed plots) in the Agatti lagoon. The exclosures had patches of seagrass growing in sand, surrounded by branches of naturally occurring Acropora corals that served as an effective long-term refuge from turtle herbivory.

Although individual studies measured multiple responses of seagrasses, for simplicity we display selected results to demonstrate the diversity of seagrass responses to heavy turtle herbivory. Details of other responses can be found in companion publications (Fourqurean et al., 2010; Lal et al., 2010; Christianen et al., 2012; Burkholder et al., 2013).

\section{RESULTS AND DISCUSSION}

A combination of recent field experiments and observational studies in multiple ocean basins where green turtle populations are increasing or exist at close to historical levels suggest that seagrass ecosystems could be significantly disrupted by heavy grazing (Figure 1). Across these, and previous (Williams, 1988; Bjorndal and Jackson, 2003; Moran and Bjorndal, 2005), studies it is apparent that turtles, when found at high densities (see Fourqurean et al., 2010; Christianen et al., 2014) can greatly reduce the density, heights, productivity, community composition, and persistence of seagrasses. However, ecosystem responses appear to vary considerably with context, with the highest densities of turtles associated with the largest shifts in community dynamics. At the extreme end of high turtle densities-typified by isolated islands like Bermuda and Derawan-turtles appear to be capable of destroying seagrass meadows by overgrazing (Fourqurean et al., 2010; Christianen et al., 2014). Whether the present high densities of turtles at these sites represents historical, pre-turtle exploitation conditions, or whether these high densities are an artifact of other human alterations of coastal food webs, like predator overexploitation, is unclear.

Sharks are the primary predators of late juvenile and adult green turtles (Heithaus et al., 2008; Heithaus, 2013), and the exploitation history of sharks varies across the study areas. In Shark Bay, tiger sharks (Galeocerdo cuvier), the primary predator of sea turtles, are abundant and likely near historical population sizes (Heithaus et al., 2012) as are green turtles (Heithaus et al., 2005). Here, turtle impacts on the structure of the canopyforming seagrasses are minimal in areas where shark risk is highest. In safer habitats, however, turtles reduce the density and biomass of seagrasses considerably (Figure 1). Near Bermuda, tiger shark populations appear to have declined dramatically since the 1980s (Baum et al., 2005), and turtle grazing greatly reduced seagrass productivity (Figure 1) such that turtles appear to be capable of driving meadows to extinction (Fourqurean et al., 2010). Similarly, fishing pressure on sharks is high in Indonesia and India and many taxa are overfished (Blaber et al., 2009; Ferretti et al., 2010). In the Lakshadweep (India) and Derawan 


\section{Many turtles*}

Western Australia: stable turtle populations; high shark populations; high risk habitat

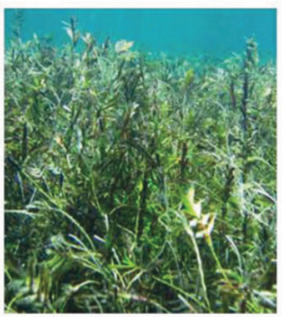

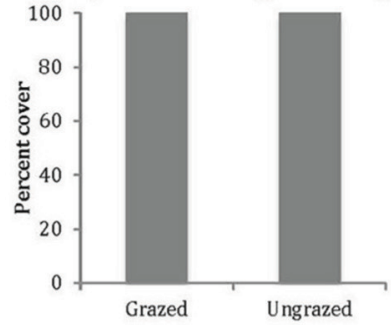

Few/No turtles

Method

(significance)

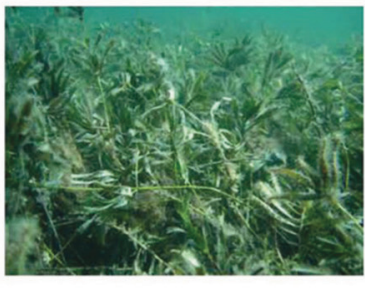

600 day exclosure

(NS)

Western Australia: stable turtle populations; high shark populations; $\underline{\text { low risk habitat }}$
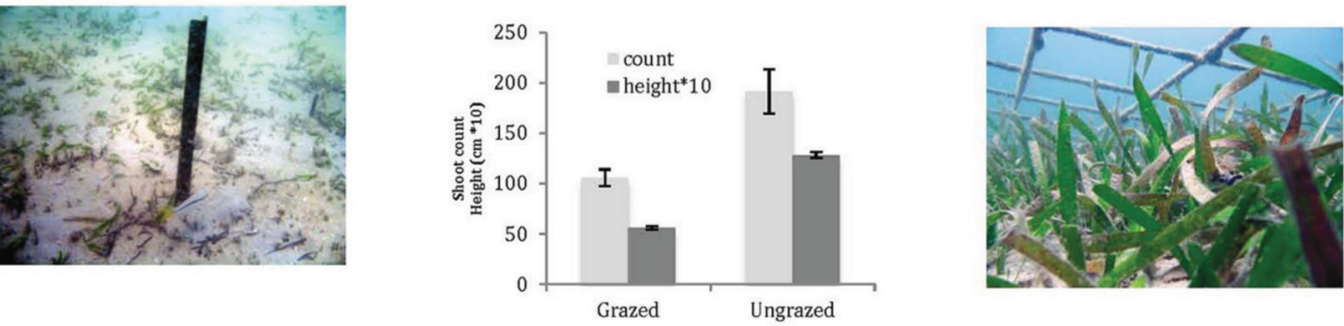

600 day exclosure (count: $\mathrm{p}<0.05$ ) (height: $\mathrm{p}<0.01$ )

Bermuda: high and rapidly increasing turtle populations; shark populations reduced
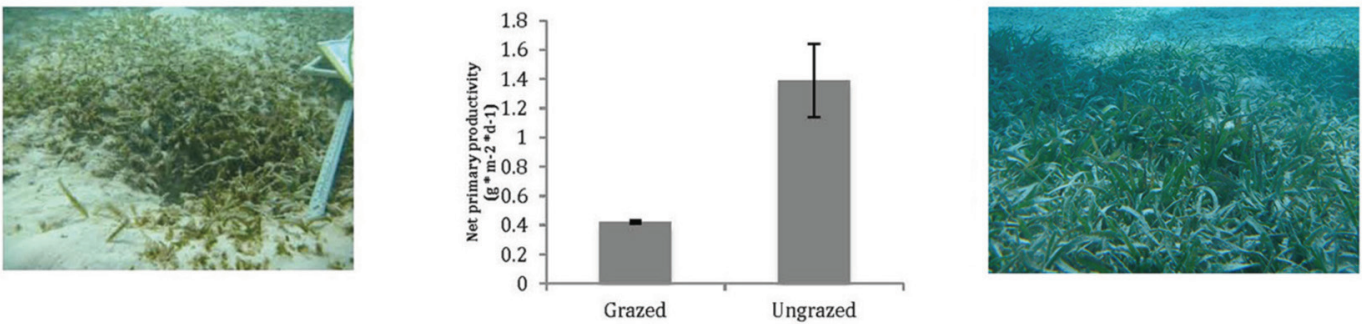

730 day exclosure $(\mathrm{p}<0.01)$

Lakshadweep, India: rebounded to high, stable turtle populations; shark populations likely reduced
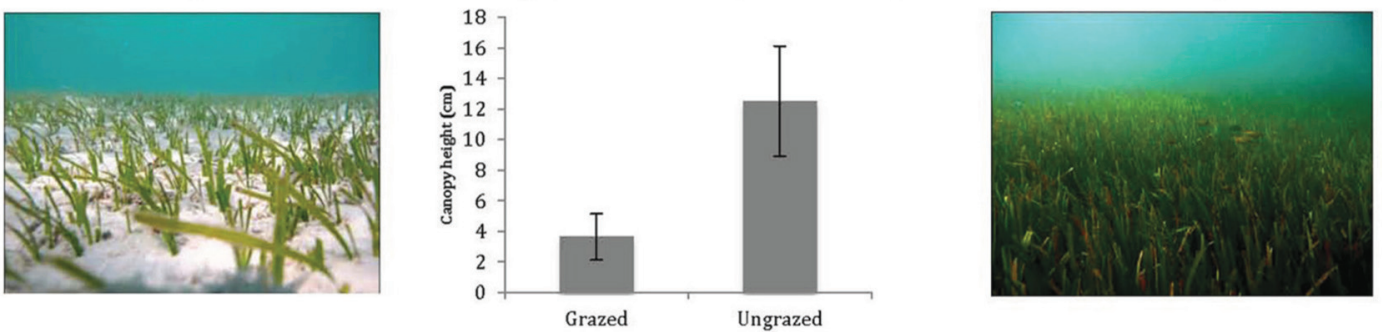

Long-term natural exclosures $(\mathrm{p}<0.0001)$,

Derawan, Indonesia: increasing turtle populations; shark populations likely reduced
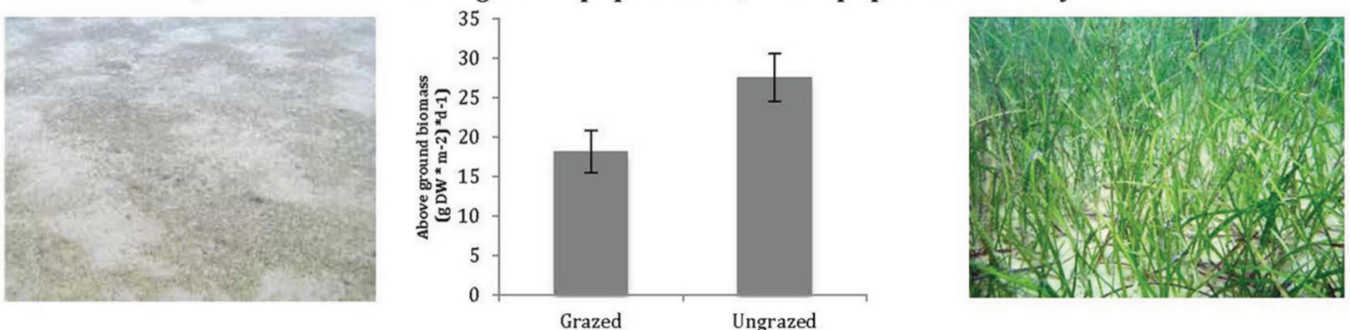

90 day exclosure $(\mathrm{p}<0.05)$

FIGURE 1 | Responses of seagrasses to green turtle grazing across ecological contexts. Although individual studies measured multiple responses of seagrasses, for simplicity we display selected results to demonstrate the diversity of seagrass responses to heavy turtle herbivory. In the Shark Bay experiments, high-risk habitats have been shown to have high probability of green turtle predation by tiger sharks, and low risk habitats are relatively safe havens for the turtles (Heithaus et al., 2007). Details of other responses can be found in companion publications (Fourqurean et al., 2010; Lal et al., 2010; Christianen et al., 2012, 2014; Burkholder et al., 2013). 
(Indonesia), high-density turtle populations have resulted in major ecosystem-wide impacts on seagrass meadows, causing community shifts and reductions in habitat structure (Figure 1) that may cascade through the ecosystem (Lal et al., 2010). In Derawan and Bermuda, the considerable decline or complete collapse of seagrasses due to turtle grazing could have considerable consequences since high-biomass seagrass areas support considerably higher populations of fishes than unvegetated bottom (Heck et al., 2003).

While it is clear that the restoration of green turtle populations can have considerable impact on seagrasses, it remains unclear whether these impacts are simply restoring seagrass ecosystems to their historic structure and function, as some have suggested (Jackson et al., 2001; Bjorndal and Jackson, 2003) or whether turtle populations, now largely released from predation in many areas (Ferretti et al., 2010; Heithaus et al., 2012), have grown beyond historical carrying capacities and are inducing ultimately detrimental phase shifts in seagrass ecosystems, as has been seen in Indonesian MPAs with high sea turtle abundances (Christianen et al., 2014). Such phase-shifts could eventually have detrimental impacts on green turtle populations. For example, in Bermuda, an isolated island in the middle of the Atlantic Ocean, the nearest seagrass meadows are over $1000 \mathrm{~km}$ distant, too far to serve as habitat for the turtles that now rely on seagrass meadows. In contrast, in Shark Bay, with intact turtle, dugong (Dugong dugon), and tiger shark (Galeocerdo cuvier) populations (Heithaus et al., 2012), seagrasses in areas of highrisk for herbivores exhibit very high biomass (Burkholder et al., 2013) and are little changed by large herbivore exclosures while seagrasses in areas of lower risk exist at moderate densities and seagrass biomass and heights are suppressed by herbivory-but not to the extent that seagrasses in areas with much higher turtle densities are. This suggests that large-scale seagrass declines in many locations with increasing turtle populations may not represent a return to a natural state and may be grazed well below seagrass biomasses that might have existed under less trophically-downgraded conditions.

It is unquestionable that further turtle conservation efforts are required in many areas of the world to restore turtle populations to levels that ensure population persistence and an intact ecological role. Indeed, the locations selected in these studies are in many cases unique in their high turtle densities even regionally and represent a very minor impact on global seagrass meadows. Therefore, conservation planning must consider the specific mechanisms through which trophic downgrading in seagrass communities might affect ecosystem structure and function (Figure 2). Specifically, the loss of turtles may lead to ecosystem degradation through eutrophication and overgrowth of seagrasses by epiphytic algae (Bjorndal and Jackson, 2003) while population explosions facilitated by loss of predators and effective conservation of turtles could lead to overgrazing. Thus, the possibility that top predators once strongly mediated turthe impacts on seagrasses needs to be explicitly included in future research and conservation planning to avoid unintended ecosystem consequences. Furthermore, there is likely a need to not only protect remaining depleted stocks of highly interactive shark species (e.g., tiger sharks), but to restore their populations.

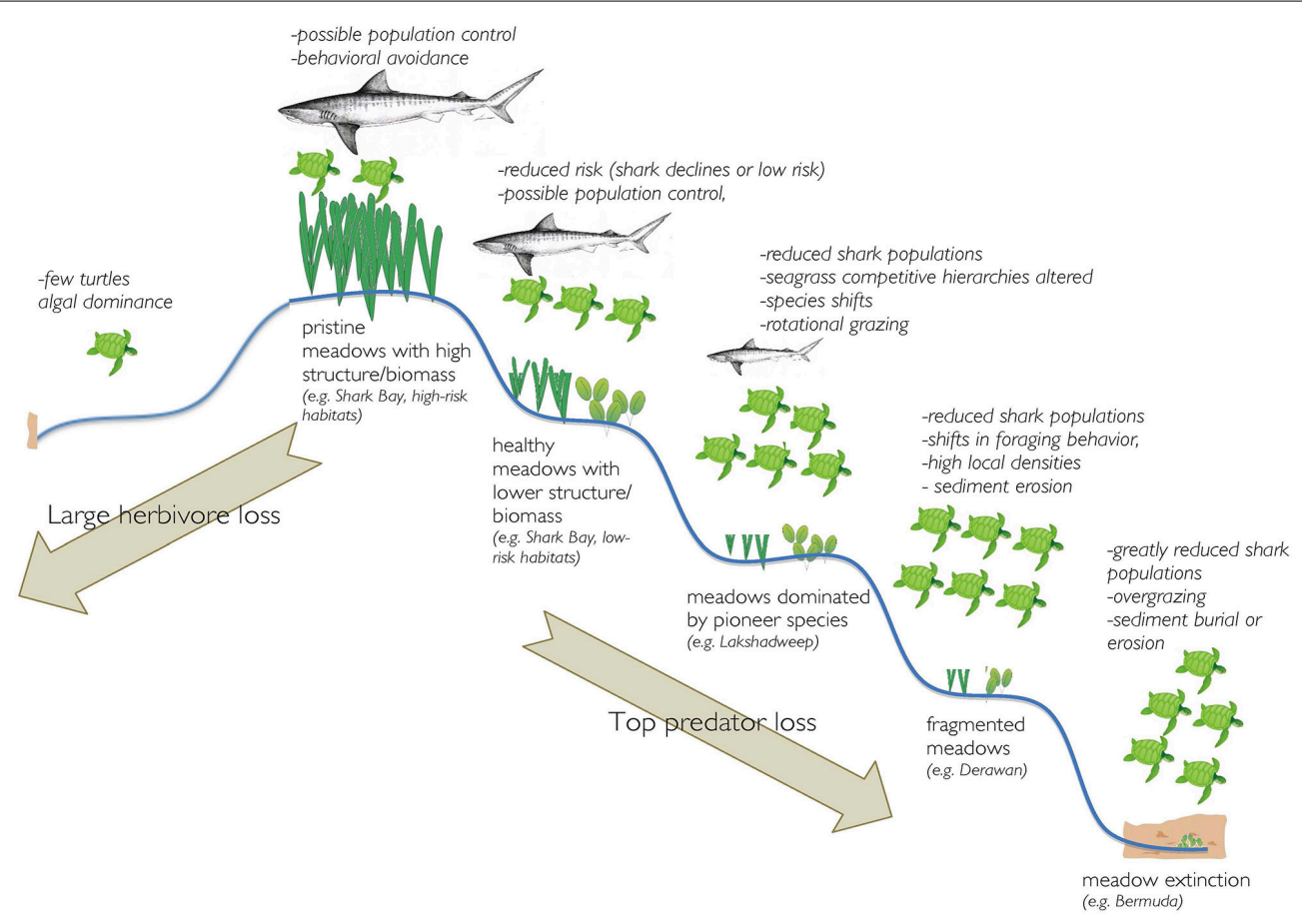

FIGURE 2 | Schematic representation of potential ecosystem responses to loss of turtles (moving from the top to the left) or loss of large sharks with turtle conservation (moving from the top to the right). 


\section{AUTHOR CONTRIBUTIONS}

Michael R. Heithaus and James W. Fourqurean led the study and drafted the manuscript. Teresa Alcoverro, Rohan Arthur, and Nachiket Kelkar contributed data from their experiments in India; Marjolijn J. A. Christianen contributed data from her experiments in Indonesia; Derek A. Burkholder, Michael R. Heithaus, Aaron J. Wirsing and James W. Fourqurean contributed data from their experiments in Australia; and Sarah A. Manuel, Kathryn A. Coates, W. Judson Kenworthy and James W. Fourqurean contributed data from their experiments in Bermuda. All co-authors commented on and provided edits to the original manuscript.

\section{ACKNOWLEDGMENTS}

Studies in Shark Bay were funded by NSF grants OCE0526065 and OCE0745606 and Florida International University. Work in India was supported by the Norwegian Institute of Nature Research, the Rufford Small Grants Programme and Spanish Ministry of Economia y Competitividad [projects: CTM2010-22273-C02-02 and PIE-201330E062 (CSIC)]. Work in Bermuda was funded by the Department of Conservation Services, Government of Bermuda and B. Dilke, a private benefactor. This is contribution \# 681 of the Southeast Environmental Research Center, Florida International University, contribution \# BBP218 of the BBP series at the Bermuda Department of Conservation Services library, and contribution 76 of the Shark Bay Ecosystem Research Project. All studies were carried out under relevant environmental permits and animal care protocols.

\section{REFERENCES}

Barbier, E. B., Hacker, S. D., Kennedy, C., Koch, E. W., Stier, A. C., and Silliman, B. R. (2011). The value of estuarine and coastal ecosystem services. Ecol. Monogr. 81, 169-193. doi: 10.1890/10-1510.1

Baum, J. K., Myers, R. A., Kehler, D. G., Worm, B., Harley, S. J., and Doherty, P. (2005). Collapse and conservation of shark populations in the Northwest Atlantic. Science 299, 389-392. doi: 10.1126/science.1079777

Bjorndal, K. A., and Jackson, J. B. C. (2003). "Roles of sea turtles in marine ecosystems: reconstructing the past," in The Biology of Sea Turtles, Vol. 2, eds P. L. Lutz, J. A. Musick, and J. Wyneken (Boca Raton, FL: CRC Press), 259-274.

Blaber, S. J. M., Dichmont, C. M., White, W., Buckworth, R., Sadiyah, L., Iskandar, B., et al. (2009). Elasmobranchs in southern Indonesian fisheries: the fisheries, the status of the stocks and management options. Rev. Fish Biol. Fish 19, 367-391. doi: 10.1007/s11160-009-9110-9

Borum, J., Pedersen, O., Greve, T. M., Frankovich, T. A., Zieman, J. C., Fourqurean, J. W., et al. (2005). The potential role of plant oxygen and sulphide dynamics in die-off events of the tropical seagrass, Thalassia testudinum. J. Ecol. 93, 148-158. doi: 10.1111/j.1365-2745.2004.00943.x

Burkholder, D. A., Fourqurean, J. W., and Heithaus, M. R. (2013). Spatial pattern in seagrass stoichiometry indicates both $\mathrm{N}$-limited and P-limited regions of an iconic P-limited subtropical bay. Mar. Ecol. Prog. Ser. 472, 101-115. doi: 10.3354/meps 10042

Chaloupka, M., Bjorndal, K. A., Balazs, G. H., Bolten, A. B., Ehrhart, L. M., Limpus, C. J., et al. (2008). Encouraging outlook for recovery of a once severely exploited marine megaherbivore. Global Ecol. Biogeogr. 17, 297-304. doi: 10.1111/j.14668238.2007.00367.x

Christianen, M. J. A., Govers, L. L., Bouma, T. J., Kiswara, W., Roelofs, J. G. M., Lamers, L. P. M., et al. (2012). Marine megaherbivore grazing may increase seagrass tolerance to high nutrient loads. J. Ecol. 100, 546-560. doi: 10.1111/j.1365-2745.2011.01900.x

Christianen, M. J. A., Herman, P. M. J., Bouma, T. J., Lamers, L. P. M., Van Katwijk, M. M., Van der Heide, T., et al. (2014). Habitat collapse due to overgrazing threatens turtle conservation in marine protected areas. Proc. R. Soc. B Biol. Sci. 281:20132890. doi: 10.1098/rspb.2013.2890

Estes, J. A., Terborgh, J., Brashares, J. S., Power, M. E., Berger, J., Bond, W. J., et al. (2011). Trophic downgrading of planet earth. Science 333, 301-306. doi: 10.1126/science. 1205106

Ferretti, F., Worm, B., Britten, B. G. L., Heithaus, M. R., and Lotze, H. (2010). Patterns and ecosystem consequences of shark declines in the ocean. Ecol. Lett. 13, 1055-1071. doi: 10.1111/j.1461-0248.2010.01489.x

Fourqurean, J. W., Duarte, C. M., Kennedy, H., Marbà, N., Holmer, M., Mateo, M. A., et al. (2012). Seagrass ecosystems as a globally significant carbon stock. Nat. Geosci. 5, 505-509. doi: 10.1038/ngeo1477

Fourqurean, J. W., Manuel, S., Coates, K. A., Kenworthy, W. J., and Smith, S. R. (2010). Effects of excluding sea turtle herbivores from a seagrass bed: overgrazing may have led to loss of seagrass meadows in Bermuda. Mar. Ecol. Prog. Ser. 419, 223-232. doi: $10.3354 /$ meps 08853

Heck, K. L., Hays, G., and Orth, R. J. (2003). Critical evaluation of the nursery role hypothesis for seagrass meadows. Mar. Ecol. Prog. Ser. 253, 123-136. doi: $10.3354 /$ meps 253123

Heck, K. L. J., and Valentine, J. F. (2007). The primacy of top-down effects in shallow benthic ecosystems. Estuar. Coasts 30, 371-381. doi: 10.1007/BF02 819384

Heithaus, M. R. (2013). "Predators, prey, and ecological roles of sea turtles," in Biology of Sea Turtles, Vol. III, eds J. Wyneken, J. K. Lohman, and J. A. Musick (Boca Raton, FL: CRC Press), 249-285. doi: 10.1201/ b13895-11

Heithaus, M. R., Frid, A., Wirsing, A. J., Bejder, L., and Dill, L. M. (2005). Biology of green and loggerhead sea turtles under risk from tiger sharks at a foraging ground. Mar. Ecol. Prog. Ser. 288, 285-294. doi: 10.3354/meps 288285

Heithaus, M. R., Frid, A., Wirsing, A. J., Dill, L. M., Fourqurean, J. W., Burkholder, D., et al. (2007). State-dependent risk-taking by green sea turtles mediates topdown effects of tiger shark intimidation in a marine ecosystem. J. Anim. Ecol. 76, 837-844. doi: 10.1111/j.1365-2656.2007.01260.x

Heithaus, M. R., Hamilton, I. M., Wirsing, A. J., and Dill, L. M. (2006). Validation of a randomization procedure to assess animal habitat preferences: microhabitat use of tiger sharks in a seagrass ecosystem. J. Anim. Ecol. 75, 666-676. doi: 10.1111/j.1365-2656.2006.01087.x

Heithaus, M. R., Wirsing, A. J., and Dill, L. M. (2012). The ecological importance of intact top-predator populations: a synthesis of 15 years of research in a seagrass ecosystem. Mar. Freshwater Res. 63, 1039-1050. doi: 10.1071/ MF12024

Heithaus, M. R., Wirsing, A. J., Thomson, J. A., and Burkholder, D. A. (2008). A review of lethal and non-lethal effects of predators on adult marine turtles. J. Exp. Mar. Biol. Ecol. 356, 43-51. doi: 10.1016/j.jembe.2007. 12.013

Jackson, J. B. C., Kirby, M. X., Berger, W. H., Bjorndahl, K. A., Botsford, L. W., Bourque, B. J., et al. (2001). Historical overfishing and the recent collapse of coastal ecosystems. Science 293, 629-638. doi: 10.1126/science.1059199

Koch, M. S., Schopmeyer, S. A., Nielsen, O. I., Kyhn-Hansen, C., and Madden, C. J. (2007). Conceptual model of seagrass die-off in Florida Bay: links to biogeochemical processes. J. Exp. Mar. Biol. Ecol. 350, 73-88. doi: 10.1016/j.jembe.2007.05.031

Lal, A., Arthur, R., Marbà, N., Lill, A. W. T., and Alcoverro, T. (2010). Implications of conserving an ecosystem modifier: increasing green turtle (Chelonia mydas) densities substantially alters seagrass meadows. Biol. Conserv. 143, 2730-2738. doi: 10.1016/j.biocon.2010.07.020

Moran, K. L., and Bjorndal, K. A. (2005). Simulated green turtle grazing affects structure and productivity of seagrass pastures. Mar. Ecol. Prog. Ser. 305, 235-247. doi: 10.3354/meps305235

Short, F. T., and Wyllie-Echeverria, S. (1996). Natural and humaninduced disturbance of seagrasses. Environ. Conserv. 23, 17-27. doi: $10.1017 /$ S0376892900038212

Waycott, M., Duarte, C. M., Carruthers, T. J. B., Orth, R. J., Dennison, W. C., Olyarnik, S., et al. (2009). Accelerating loss of seagrasses across the globe threatens coastal ecosystems. Proc. Natl. Acad. Sci. U.S.A. 106, 12377-12381. doi: 10.1073/pnas.0905620106

Williams, S. L. (1988). Thalassia testudinum productivity and grazing by green turtles in a highly disturbed seagrass bed. Mar. Biol. 98, 447-455. doi: 10.1007/BF00391121 
Zarnetske, P., Skelly, D. K., and Urban, M. C. (2012). Biotic multipliers of climate change. Science 336, 1516-1518. doi: 10.1126/science. 1222732

Zieman, J. C. (1974). Methods for the study of the growth and production of turtle grass, Thalassia testudinum König. Aquaculture 4, 139-143. doi: 10.1016/00448486(74)90029-5

Conflict of Interest Statement: The authors declare that the research was conducted in the absence of any commercial or financial relationships that could be construed as a potential conflict of interest.

Received: 01 June 2014; paper pending published: 01 July 2014; accepted: 11 July 2014; published online: 05 August 2014.
Citation: Heithaus MR, Alcoverro $T$, Arthur $R$, Burkholder DA, Coates KA, Christianen MJA, Kelkar N, Manuel SA, Wirsing AJ, Kenworthy WJ and Fourqurean JW (2014) Seagrasses in the age of sea turtle conservation and shark overfishing. Front. Mar. Sci. 1:28. doi: 10.3389/fmars.2014.00028

This article was submitted to Marine Ecosystem Ecology, a section of the journal Frontiers in Marine Science.

Copyright (c) 2014 Heithaus, Alcoverro, Arthur, Burkholder, Coates, Christianen, Kelkar, Manuel, Wirsing, Kenworthy and Fourqurean. This is an open-access article distributed under the terms of the Creative Commons Attribution License (CC BY). The use, distribution or reproduction in other forums is permitted, provided the original author(s) or licensor are credited and that the original publication in this journal is cited, in accordance with accepted academic practice. No use, distribution or reproduction is permitted which does not comply with these terms. 